\title{
PERSEPSI PETANI PERKOTAAN TERHADAP KEGIATAN BUDIDAYA TANAMAN SAYURAN ORGANIK DI KOTA BENGKULU (Studi Kasus pada Kelompok Tani Melati di Kelurahan Kandang Limun)
}

\author{
URBAN FARMERS' PERCEPTION TO ORGANIC \\ VEGETABLE PRODUCTION ACTIVITIES AT BENGKULU CITY \\ (A Case Study of Melati Farmer Group in Kandang Limun Village) \\ Nola Windirah ${ }^{1}$, Nanik Setyowati $^{{ }^{*}}$, Zainal Muktamar $^{2}$, Fahrurrozi $^{2}$ \\ ${ }^{1}$ Jurusan Sosial Ekonomi Pertanian Universitas Bengkulu, Jl. W.R. Supratman, Bengkulu. \\ ${ }^{2}$ Jurusan Budidaya Pertanian Universitas Bengkulu, Jl. W.R. Supratman, Bengkulu. \\ *Email: nsetyowati@unib.ac.id \\ (Diterima 13-11-2020; Disetujui 29-12-2020)
}

\begin{abstract}
ABSTRAK
Pandemik Covid-19 memberikan dampak yang sangat luar biasa terhadap keseharian masyarakat dunia, termasuk masyarakat Kota Bengkulu. Kelompok tani merupakan salah satu unit sosial yang strategis untuk meningkatkan produktivas pertanian dan taraf hidup petani, serta kemampuan beradaptasi dengan kondisi yang kurang menguntungkan. Kelompok Tani Melati Kelurahan Kandang Limun yang memiliki latar belakang aktifitas memproduksi tanaman pangan dapat diperkenalkan dengan produksi tanaman sayuran untuk menopang kebutuhan hidupnya. Penelitian bertujuan untuk menganalisis persepsi petani terhadap tingkat pengetahuan, kebermanfaatan dan keberlanjutan produksi sayuran organik di Kota Bengkulu. Penelitian menggunakan metode analisis deskriptif dari data kuesioner responden. Hasil penelitian menyimpulkan bahwa persepsi anggota Kelompok Tani Melati terhadap pengetahuan, kebermanfaatan dan keberlajutan tanaman sayuran organik tinggi.
\end{abstract}

Kata kunci: Covid-19; Kelompok Tani; Persepsi Petani; Sayuran Organik

\begin{abstract}
The Covid-19 pandemic has tremendous impacts on the daily lives of the world community, including the people of Bengkulu City. The Farmer Group is one of the strategic social units to increase agricultural productivity and increase farmers' living standards and adaptability to unfavorable conditions. The Melati Farmer Group, Kandang Limun, which has a background in the activity of producing food crops, can be introduced to the production of vegetable crops to support their daily needs. This study aims to analyze farmers' perceptions of the level of knowledge, benefits, and sustainability of organic vegetable production in Bengkulu City. The research used descriptive analysis method from the respondent's questionnaire data. The results of the study concluded that the perception of the members of the Melati Farmers Group on the knowledge, usefulness and sustainability of organic vegetable crops was considered high.
\end{abstract}

Key words: Covid-19; Farmer Group; Farmer Perceptions; Organic Vegetables

\section{PENDAHULUAN}

Pandemi Covid-19 yang melanda dunia sejak akhir tahun 2019 telah memberikan dampak negatif terhadap
perekonomian dunia, termasuk
perekonomian Indonesia dan Kota
Bengkulu. Himbauan agar mengurangi
aktivitas di luar rumah, bekerja dari 
rumah dan menjaga jarak merubah ritme dan peluang kerja masyarakat untuk menghidupi keluarganya. Hasil pengamatan awal di Kota Bengkulu menunjukkan bahwa masyarakat bermata pencaharian sebagai petani, buruh harian lepas, pedagang kecil, pekerja informal dan mereka yang berada di sekitar garis kemiskinan merupakan kelompok masyarakat yang paling terpapar dalam kondisi ini. Mereka kehilangan daya beli, bahkan daya hidup, karena pendapatannya berkurang atau tidak berpendapatan sama sekali, karena tidak dapat menawarkan jasa dan keterampilan ke konsumen. Dengan demikian, petani di kawasan perkotaan merupakan salah satu kelompok yang rentan terhadap dampak Covid-19.

Kelompok tani merupakan salah satu unit sosial yang strategis digunakan pemerintah untuk meningkatkan produktivas pertanian dan meningkatkan taraf hidup petani. Demikian juga dalam situasi yang kurang menguntungkan, termasuk terjadinya krisis ekonomi dan sosial akibat pandemik Covid-19, kelompok tani tetap dapat diandalkan untuk meningkatkan kemampuan masyarakat dalam menghadapi situasi yang kurang menguntungkan. Menurut Badan Pusat Statistik (2018), jumlah kelompok tani di Kota Bengkulu sebanyak 347 dan tersebar pada sembilan kecamatan. Karakteristik kegiatan pertanian yang menjadi fokus anggotanya adalah produksi tanaman pangan, khususnya tanaman padi sawah. Karena lokasinya, kelompok tani yang ada di perkotaan, memiliki jenis pola kegiatannya berbeda dengan kelompok tani yang ada di pedesaan. Kegiatan pertanian menjadi sumber utama pendapatan mereka, namun di waktu senggang, petani menyempatkan diri utuk menjadi buruh tani, buruh bangunan atau kegiatan tambahan produktif lainnya, termasuk berjualan dan menawarkan jasa buruh lepas paruh waktu untuk meningkatkan pendapatan keluarganya.

Penguatan kelompok tani di kawasan perkotaan harus dilakukan sesuai dengan karakteristik kelompok, dan peluang memanfaatkan masyarakat dan harus dilakukan sebagai bentuk dari partisipasi masyarakat dalam penguatan ekonomi masyarakat perkotaan. Penguatan Kelompok Tani Melati Kota Bengkulu dapat dilakukan melalui kegiatan produksi sayuran untuk menjadi sumber pendapatan 
sangat mungkin dilakukan, karena (1) memiliki pengalaman budidaya tanaman, (2) sedang membutuhkan tambahan pendapatan untuk memenuhi kebutuhan keluarga, (3) memahami pola permintaan tanaman sayuran, dan (4) konsumen membutuhkan sayuran yang segar dan dijual dengan jasa antar alamat.

Penyediaan tanaman sayuran untuk memenuhi kebutuhan gizi mayarakat harus dilakukan agar tingkat kesehatan dan kekebalan tubuh masyarakat meningkat. Imunitas tubuh menjadi peran yang sangat penting dalam menghadapi masa Pandemi Covid-19, mengingat virus Covid-19 saat ini hanya bisa dimusnahkan oleh imun tubuh sendiri. Oleh karena itu, asupan makanan dan minuman yang masuk ke tubuh menjadi perhatian khusus dalam pembentukan imun. Vitamin A, E, C, selenium, zat besi, dan zinc diketahui dapat mendorong produksi imun pada tubuh (Siswanto et al, 2013). Sebagian besar vitamin dan seluruh mineral tidak dapat disintesa oleh tubuh, sehingga mengkonsumsi makanan yang beragam dan berimbang akan sangat dibutuhkan seperti buah, sayuran, dan pangan hewani. Instalasi Gizi RSUPN Dr Cipto Mangunkusumo (2020) mengeluarkan anjuran terkait makanan beragam dan berimbang dalam masa pandemi Covid-19. Anjuran berupa porsi sayur yang mencapai $2 / 3$ dari $1 / 2$ piring menunjukkan bahwa peran sayur cukup penting dalam pemenuhan konsumsi bergizi masyarakat.

Kualitas sayuran yang baik akan menjamin pemenuhan gizi yang diserap oleh tubuh. Pertanian dengan metode organik dapat menjadi solusi dalam penjaminan kualitas sayur. Volume perdagangan produk organik di Indonesia terbilang rendah. Sedangkan, potensi lahan yang dimiliki sangat luas dan potensi bahan baku untuk pupuk organik sangat besar (Chrysanthini et al, 2017).

Berdasarkan faktor penarik (potensi pengembangan) dan pendorong (Pandemi Covid-19) terhadap keberadaan sayuran organik, maka perlu diadakan sebuah penelitian untuk mengetahui persepsi masyarakat terhadap tingkat pengetahuan, kemanfaatan dan keberlanjutan sayuran organik. Aditiawati et al (2014), Widiyastuti et al (2016), Chrysanthini, et al (2017), Iskandar dan Nurtilawati (2019) menyatakan bahwa tingkat persepsi petani terhadap sebuah inovasi akan mempengaruhi sikap mereka dalam menjalankan inovasi tersebut. Oleh karena itu, persepsi petani terhadap 
inovasi sayuran organik diharapkan dapat mengukur sikap petani terhadap pengaplikasian tanaman sayuran organik di kehidupan mereka. Namun demikian, informasi tentang kesiapan masyarakat tani di Kota Bengkulu, khususnya kelompok tani terhadap produksi tanaman sayuran secara organik untuk merespon perkembangan pandemi Covid19 belum tersedia. Penelitian ini bertujuan untuk (1) menganalisis persepsi petani terhadap tingkat pengetahuan, (2) kemanfaatan, dan (3) keberlanjutan sayuran organik di Kota Bengkulu.

\section{METODE PENELITIAN}

\section{Lokasi Penelitian}

Penelitian ini dilakukan di Kelompok Tani Melati Kecamatan Muara Bangkahulu Kota Bengkulu pada bulan September 2020. Pemilihan lokasi dilakukan secara sengaja (purposive) dengan alasan bahwa Kelompok Tani Melati Kecamatan Muara Bangkahulu Kota Bengkulu merupakan satu-satunya kelompok tani yang berstatus Madya di Kecamatan Muara Bangkahulu, sehingga penyerapan informasi baru akan mudah dicapai dengan baik. Selain itu, hasil temuan dapat menjadi tolok ukur dalam pengembangan tanaman sayur organik di kelompok tani lainnya yang berada di Kota Bengkulu.

\section{Metode Analisis}

Motode analisis yang digunakan dalam penelitian yakni metode deskriptif, yaitu pemanfaatan interpretasi yang tepat dalam mencari fakta. Mempelajari permasalahan-permasalahan yang terjadi di masyarakat, tatacara yang berlaku serta situasi-situasi tertentu, hubungan, kegiatan-kegiatan, sikap-sikap, pandangan-pandangan, serta prosesproses yang sedang terjadi, hingga pengaruh-pengaruh dari suatu fenomena menjadi hal yang diperhatikan dalam penelitian deskriptif. Nazir (1988) menyatakan bahwa teknik penelitian yang digunakan dalam deskriptif yakni teknik studi kasus, yaitu penelitian tentang status subjek penelitian (individu, kelompok, lembaga, masyarakat) yang behubungan dengan satu fase spesifik dari keseluruhan personalitas.

\section{Responden}

Jumlah responden sebanyak 14 orang ditentukan berdasarkan hasil sensus terhadap total anggota Kelompok Tani Melati Kecamatan Muara Bangkahulu Kota Bengkulu yang mengikuti kegiatan pelatihan penanaman 
sayuran organik yang dilaksanakan di wilayah Kecamatan Muara Bangkahulu.

\section{Sumber Data}

Data yang digunakan dalam penelitian ini yakni data primer yang berasal dari kuesioner. Data primer yang dimaksud meliputi karakteristik petani dan persepsi petani yang dibagi berdasarkan kategori pengetahuan, kemanfaatan, dan keberlanjutan tanaman sayur organik. Penilaian persepsi diukur melalui skala likert dengan skor 1 (Tidak Tahu/Tidak Pernah/Tidak Setuju/Tidak Tersedia), 2 (Kurang Tahu/Kadangkadang/Kurang Setuju/Kadang-kadang), dan 3 (Tahu/Sering/Setuju/Tersedia/Ya). Selanjutnya dari data skala likert dianalisis dengan menghitung:

1. Skor minimal yakni skor jawaban terkecil dari setiap kategori pertanyaan.

2. Skor maksimal yakni skor jawaban terbesar dari setiap kategori pertanyaan.

3. Interval yakni nilai jarak kelas persepsi.

Berdasarkan data tersebut, maka persepsi petani terhadap tanaman sayur organik dikategorikan sebagai berikut:

a. Pengetahuan:

Rendah $(7,00-7,06)$
Sedang $\quad(7,07-8,03)$

Tinggi $(8,04-9,00)$

b. Kebermanfaatan:

Rendah $(13,00-13,06)$

Sedang $\quad(13,07-14,03)$

Tinggi $\quad(14,04-15,00)$

c. Keberlanjutan:

Rendah $(4,00-4,03)$

Sedang $(4,04-4,07)$

Tinggi $(4,08-5,00)$

\section{HASIL DAN PEMBAHASAN}

\section{Karakteristik Petani}

Lama tinggal petani di Kecamatan Muara Bangkahulu rata-rata 25 tahun, sehingga pemahaman mereka terkait kondisi wilayah sudah sangat baik, sehingga pertanyaan terkait kecocokan wilayah terhadap pengembangan sayuran organik sudah sangat tepat diberikan kepada anggota Kelompok Tani Melati.

Selama bermukim di Muara Bangkahulu, anggota Kelompok Tani Melati rata-rata telah menjalankan usahatani padi selama 10 tahun. Angka tersebut terbilang cukup lama, sehingga dapat disimpulkan bahwa respon mereka terhadap sebuah inovasi baik dan akan mudah untuk membandingkan dampak ekonomi yang diperoleh melalui tambahan kegiatan usahatani lainnya. 
Purwanto dan Taftazani (2018) menyebutkan bahwa jumlah tanggungan keluarga akan mempengaruhi tingkat kesejahteraan keluarga apabila memang tidak diimbangi dengan pendapatan yang cukup, sehingga jumlah tanggungan keluarga akan terus berbanding lurus dengan jumlah pendapatan sebagai patokan kesejahteraan keluarga.

Hasil penelitian menunjukkan bahwa rata-rata jumlah tanggungan keluarga anggota Kelompok Tani Melati berjumlah 4 orang. Jumlah tanggungan keluarga responden terbilang cukup banyak, oleh karena itu tawaran untuk menambah kegiatan usahatani berupa penanaman sayuran organik diharapkan mampu menambah pendapatan rumah tangga yang pada akhirnya akan menjamin kesejahteraan keluarga.

Komoditas padi merupakan komoditas utama yang diusahakan oleh anggota Kelompok Tani Melati Kecamatan Muara Bangkahulu. Kepemilikan lahan padi untuk seluruh anggota cukup luas yakni rata-rata 1 ha. Selain itu, Kelompok Tani Melati juga memiliki komoditas sampingan yakni tanaman sayuran. Pemilihan tanaman sayuran sebagai komoditas sampingan padi yakni adanya kesadaran terhadap pentingnya pemenuhan kebutuhan sayuran untuk keluarga sebagai penunjang kesehatan. Oleh karena itu, penawaran tanaman sayuran organik pada Kelompok Tani Melati dianggap sudah tepat.

\section{Persepsi Petani terhadap Pengetahuan Tanaman Sayur Organik}

Persepsi petani terkait pengetahuan terhadap tanaman sayur organik tinggi, ditemukan sebanyak $85,71 \%$ petani memiliki pengetahuan yang baik terkait informasi tentang tanaman sayuran organik, kelebihan dan manfaat sayuran organik, serta pengetahuan terkait kecocokan wilayah tanam sayur organik. Selebihnya terbagi rata diantara memiliki pengetahuan sedang $(7,14 \%)$ dan rendah (7,14\%) (Gambar 1).

Notoatmodjo (2007) menyatakan bahwa informasi menjadi salah satu faktor yang mempengaruhi pengetahuan seseorang, dimana apabila seseorang mempunyai sumber informasi yang lebih baik, akurat, dan banyak maka akan memberikan pengetahuan yang jelas berdasarkan sumber informasi tersebut.

Kegiatan pelatihan penanaman sayur organik yang telah dilakukan oleh tim peneliti kepada anggota Kelompok Tani Melati menjadi sumber informasi yang tepat bagi anggota untuk 
meningkatkan pengetahuan terkait sayuran organik itu sendiri. Kegiatan pelatihan yang diawali dari sosialisasi terkait dunia sayuran organik menyebabkan anggota Kelompok Tani Melati lebih memahami terkait kelebihan, manfaat, dan wilayah tanam yang cocok untuk sayuran organik.

Informasi mengenai kelebihan sayur organik ditangkap dengan sangat baik oleh $85,71 \%$ petani, dan seluruh petani $(100 \%)$ memahami dengan sangat baik terhadap informasi manfaat sayur organik, serta $90 \%$ petani menyerap informasi kecocokan wilayah tanam sayur organik dengan sangat baik.

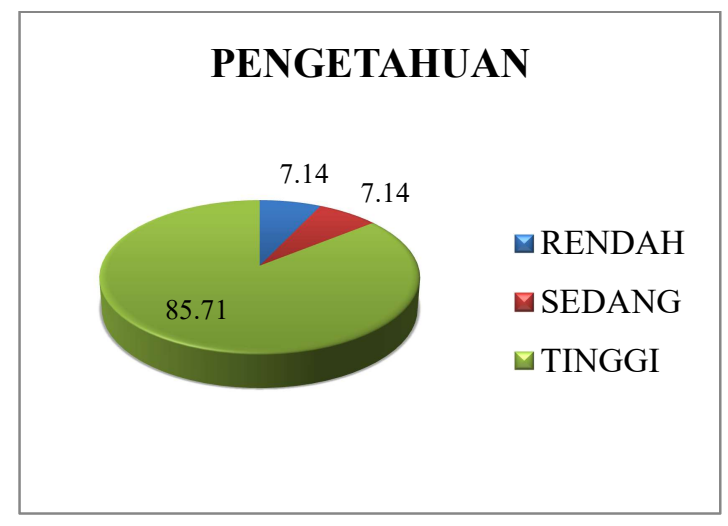

Gambar 1. Persentase persepsi petani terhadap pengetahuan sayuran organik

\section{Persepsi Petani Terhadap Kemanfaatan Tanaman Sayur Organik}

Kemanfaatan yang dimaksud dalam hal ini berupa kemanfaatan ekonomi bagi rumah tangga yang diterima oleh responden dari keberadaan tanaman sayuran organik. Sebanyak $78,57 \%$ petani berpersepsi bahwa melalui kegiatan penanaman sayuran organik maka akan meningkatkan pendapatan rumah tangga mereka, sedangkan 14,29\% petani beranggapan ragu bahwa tanaman sayuran organik dapat meningkatkan pendapatan rumah tangga. Sedangkan sebanyak $7,14 \%$ petani beranggapan bahwa keberadaan kegiatan penanaman sayuran organik tidak akan meningkatkan pendapatan rumah tangga mereka (Gambar 2).

Purwanto et al (2019) menemukan bahwa budidaya sayuran organik berbasis kemitraan dan berwawasan lingkungan dapat meningkatkan ekonomi rumah tangga. Oleh karena itu, persepsi Kelompok Tani Melati terhadap kemanfaatan ekonomi dari sayuran organik sudah sangat tepat. Selain itu, $80 \%$ petani sangat ingin menyalurkan informasi terkait kemanfaatan ekonomi dari sayuran organik kepada masyarakat lainnya, sedangkan sisanya $20 \%$ berada dipilihan ingin untuk ikut menyebarkan informasi. Permana dan Darwanto (2016) menyebutkan bahwa peran kelompok tani dalam pengembangan ekonomi lokal sangat diperlukan sebagai media belajar, solusi permasalahan tanam, dan media pemasaran produk. Hal ini dapat membuktikan bahwa pemilihan 
Kelompok Tani Melati sebagai penerima informasi pelatihan penanaman sayuran organik sudah sangat tepat dalam rangka meningkatkan perekonomian lokal.

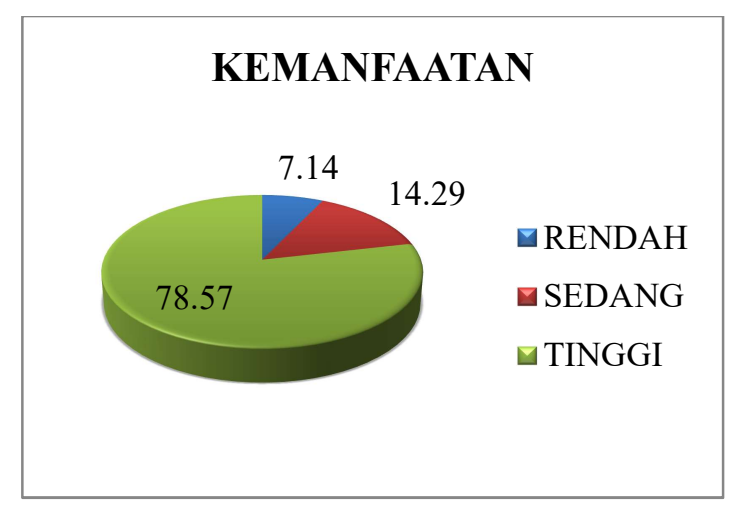

Gambar 2. Persentase persepsi petani terhadap kemanfaatan sayuran organik

\section{Persepsi Petani terhadap Keberlanjutan Tanaman Sayuran Organik}

Keberlanjutan meliputi potensi pengembangan tanaman sayuran organik berdasarkan suhu, iklim, air, dan tanah. Selain itu, potensi pengembangan yang akan dilakukan oleh masyarakat selain anggota Kelompok Tani Melati juga menjadi pertimbangan keberlanjutan.

Hasil penelitian menemukan bahwa $92,86 \%$ petani memiliki persepsi yang tinggi terkait kecocokan suhu, iklim, air dan tanah di daerah mereka untuk melakukan pengembangan sayuran organik. Selebihnya 7,14\% beranggapan wilayahnya tidak cocok untuk dilakukan pengembangan sayuran organik (Gambar $3)$.
Widowati et al (2018) menyebutkan bahwa lahan yang dapat digunakan untuk budidaya sayuran organik harus mempunyai kondisi lingkungan yang optimum, baik suhu, kelembaban, penyinaran, tidak tercemar bahan kimia, mudah diolah dan pengairan cukup. Namun, keadaan demikian dapat dipersiapkan terlebih dahulu untuk mendapatkan lingkungan pertanaman yang baik. Sutariati et al (2018) menemukan bahwa pengembangan sayuran organik dapat dilakukan di lahan pekarangan.

Anggota Kelompok Tani Melati yakin $(50 \%)$ bahwa pengembangan sayuran organik akan dilakukan oleh masyarakat sekitar di luar keanggotaan Kelompok Tani Melati, sedangkan selebihnya 50\% lagi merasa sangat yakin masyarakat akan melakukan pengembangan setelah mengetahui informasi-informasi terkait tanaman sayuran organik.

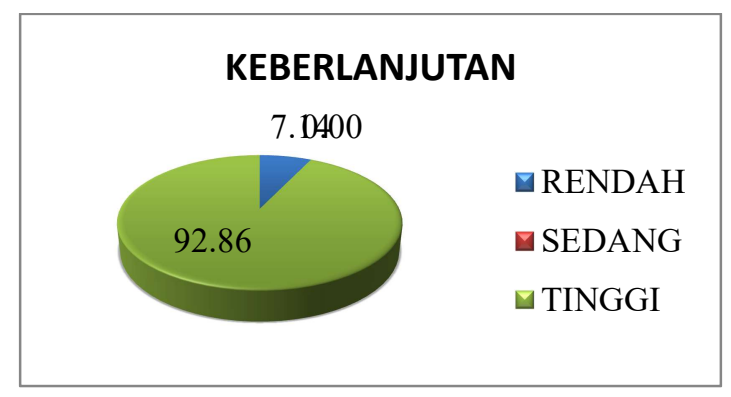

Gambar 3. Jumlah persepsi petani terhadap keberlanjutan sayuran organik 


\section{KESIMPULAN}

1. Persepsi anggota Kelompok Tani Melati terhadap pengetahuan tanaman sayuran organik tinggi yakni sebesar $85,71 \%$ petani mengetahui tentang kelebihan dan manfaat sayuran organik terhadap kesehatan, serta mengetahui tentang tipe wilayah yang cocok untuk dilakukan penanaman sayuran organik.

2. Variabel kebermanfaatan menemukan hasil bahwa sebanyak $78,57 \%$ petani dari Kelompok Tani Melati sepakat bahwa tanaman sayuran organik sangat mampu meningkatkan perekonomian rumah tangga mereka.

3. Sebanyak $92,86 \%$ anggota Kelompok Tani Melati sangat yakin akan menerapkan kegiatan budidaya sayuran organik di rumah tangga masing-masing.

\section{UCAPAN TERIMA KASIH}

Ucapan terima kasih ditujukan kepada LPPM UNIB yang telah menyediakan dana untuk kegiatan ini berdasarkan kontrak penelitian No: 2382/UN30.15/AM/2020.

\section{DAFTAR PUSTAKA}

Aditiawati, P., Rosmiati, M., \& Sumardi, D. (2014). Persepsi Petani terhadap Inovasi Teknologi Pestisida Nabati
Limbah Tembakau (Suatu Kasus pada Petani Tembakau di Kabupaten Sumedang). Sosiohumaniora, 16 (2):184-192.

Badan Pusat Statistik. (2018). Kota Bengkulu dalam Angka. 2018. 406 halaman

Chrysanthini, B., Sumarwan, U., \& Rifin, A. (2017). Preferensi Konsumen terhadap Produk Sayuran Organik (Studi Kasus Konsumen UD Fabela-Myfarm) di Bogor Jawa Barat. Manajemen IKM, 12(2):151160.

Instalasi Gizi. 2020. Makanan Bergizi untuk Menjaga Kesehatan Tubuh. Kementerian Kesehatan Republik Indonesia, Jakarta.

Iskandar, E., \& Nurtilawati, H. (2019). Persepsi Petani dan Penerapan Teknologi Pengelolaan Tanaman Terpadu di Desa Sukaresmi Kabupaten Bogor. Jurnal Agribisnis Terpadu, 203-216.

Nazir, M. (1988). Metode Penelitian. Ghalia Indonesia, Jakarta.

Notoatmodjo S. (2007). Pendidikan dan Perilaku Kesehatan. Rineka Cipta, Jakarta.

Permana, I., \& Darwanto. (2016). Peran Kelompok Tani Sayuran Organik terhadap Pengembangan Ekonomi Lokal (Studi Kasus Desa Batur, Kabupaten Semarang).

Purwanto, A., \& Taftazani, B.M. (2018). Pengaruh Jumlah Tanggungan terhadap Tingkat Kesejahteraan Ekonomi Keluarga Pekerja K3L Universitas Padjajaran. Jurnal Pekerja Sosial, 1(2): 33-43.

Purwanto, D., Sugiarto, C., Suryanadi, P., Risfandy, T., Sunarjanto, \& Purnama. M. Y. I. (2019). Peningkatan Ekonomi Rumah Tangga Melalui Budidaya Sayuran Organik Berbasis Kemitraan dan Berwawasan Lingkungan di 
Kelurahan Jebres Surakarta. Jurnal Semar, 8(1):50-54.

Siswanto, Budisetyawati, \& Ernawati, F. (2013). Peran Beberapa Zat Gizi Mikro dalam Sistem Imunitas. Gizi Indon, 36(1):57-64.

Sutariati, G. A. K., Safuan, L.O., Muhidin, \& Hasid, R. (2018). Pengembangan Sayuran Organik pada Lahan Pekarangan untuk Meningkatkan Kesehatan Masyarakat di Kota Kendari. Adimas, 22(2): 161-166.
Widiyastuti, E., \& Sutarto, Y. (2016). Persepsi Petani terhadap Pengembangan System of Rice Intensification (SRI) di Kecamatan Moga Kabupaten Pemalang. Agrista, 4(3):476-485.

Widowati, L. R., Setyorini, D., Hartatik, W., Purnomo, J., Haryati, U., Wiratno, \& Samsudin. (2018). Sistem Budi Daya Sayuran Organik. Balitbang, Jakarta. 